\title{
Synthesis and Spectroscopic Characterization of Blue Copper Model Schiff Base Complexes $\uparrow$
}

\author{
A. KULANDAISAMY ${ }^{\mathrm{a}^{*}}$, T. KAVITHA ${ }^{\mathrm{b}}, \mathrm{S}$. ANGAIARKANNI ${ }^{\mathrm{c}}$ and P. THILLAIARASU ${ }^{\mathrm{d}}$ \\ ${ }^{a}$ Department of Chemistry, Raja Doraisingam Government Arts College, \\ Sivagangai -630561, India \\ ${ }^{\mathrm{b}}$ Department of Chemistry, Sri Ramasamy Naidu Memorial College, Sattur - 626203, India \\ ${ }^{\mathrm{c}}$ Department of Chemistry, Alagappa Government Arts College, Karaikudi -630003, India \\ ${ }^{\mathrm{d}}$ Department of Chemistry, Kalasalingam University, Krishnankoil - 626190, India \\ kulandai.kvn@gmail.com
}

Received 9 January 2013 / Accepted 15 February 2013

\begin{abstract}
Low molecular weight, low symmetric complexes simulating blue copper protein have been prepared by a reaction between salicylidene-4-aminoantipyrinyl-2-imino pyridine and metal salts. The complexes were characterized by elemental analysis, molar conductivity, magnetic susceptibility data, IR, ${ }^{1} \mathrm{H}$ NMR, UV-Vis, FAB-Mass and EPR spectral studies. The physicochemical studies and spectral data indicate that the ligand acts as a monovalent tridentate chelating agent. All the complexes have the general composition MLX (M= Cu(II), Ni(II), $\mathrm{Co}(\mathrm{II})$ and $\mathrm{Zn}(\mathrm{II}) ; \mathrm{L}=$ Schiff base and $\mathrm{X}=\mathrm{Cl} / \mathrm{Br} / \mathrm{OAc})$. The UV-Vis., cyclic voltammetry and EPR spectral data of the complexes suggested that $[\mathrm{CuLCl}]$ complex is mimic the blue copper model type 1 proteins. But other two copper complexes are square planar geometry around the central metal ion and they were non-model complexes.
\end{abstract}

Keywords: Blue copper protein, Synthesis, Schiff base complexes, Spectroscopic characterization

\section{Introduction}

Proteins containing iron(II) or copper(II) are of fundamental importance to the animal life due to their reversible reactions with molecular oxygen ${ }^{1}$. These proteins can bind, transport, store and release dioxygen where required. The essential requirement of the Schiff base which can act as model to mimic the oxygen carrying property of natural system is that it should possess at least two nitrogen donors, with the others being nitrogen, oxygen, sulphur or a combination of the three. Among the various types of ligands, macrocyclic ligand systems and their metal complexes are used as bioinorganic models. Naturally occurring blue copper proteins are characterized by a distorted or flattened tetrahedral geometry around the central metal ion. It appears therefore that a prime requisite for the synthesis of a near model compound, that has structural resemblance to blue copper proteins should be that the chosen ligand system must be able to dictate a highly distorted tetrahedral coordination around copper(II) ${ }^{2}$. A search through the literature reveals that a number of attempts have been made for the synthesis of blue copper proteins but no attempt has been done for the

$\uparrow$ Presented to the National Conference on Chemistry Solutions at SRM University, India 
preparation of blue copper model from 4-aminoantpyrine precursor ${ }^{3-16}$. Hence, we take an attempt for the synthesis of new copper complexes using salicylidene-4-aminoantipyrine and 2-aminopyridine.

\section{Experimental}

An ethanolic solution $(50 \mathrm{~mL})$ of salicylidene-4-aminoantipyrine $(3.07 \mathrm{~g}, 0.01 \mathrm{~mol})$ and 2-aminopyridine $(0.94 \mathrm{~g}, 0.01 \mathrm{~mol})$ was boiled in the presence of anhydrous sodium carbonate under reflux on a water bath for $24 \mathrm{~h}$. Then the resulting mixture was filtered and the solution was concentrated. The brown pasty mass obtained was stirred with $50 \mathrm{~mL}$ of distilled water. The solid obtained was filtered and recrystallised from ethanol (Scheme 1).<smiles>Cc1c(/N=C/c2ccccc2O)c(=O)n(-c2ccccc2)n1C</smiles><smiles>Cc1c(/N=C/c2ccccc2O)/c(=N/c2ccccc2)n(-c2ccccc2)n1C</smiles>

Scheme 1

\section{Synthesis of the complexes}

An ethanolic solution of $\mathrm{CuCl}_{2} / \mathrm{CuBr}_{2} / \mathrm{Cu}(\mathrm{OAc})_{2}(0.05 \mathrm{~mol})$ and Schiff base $(0.05 \mathrm{~mol})$ was stirred for $6 \mathrm{~h}$. The precipitated complexes was filtered, washed with ethanol and dried (Scheme 2).

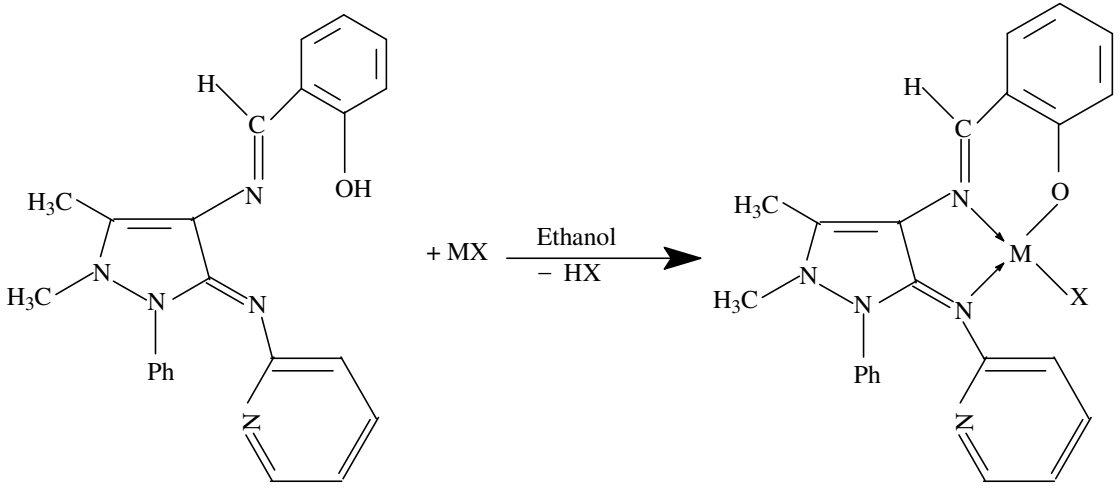

Where, $\mathrm{M}=\mathrm{Cu}^{2+}$ or $\mathrm{Zn}^{2+}$ and $\mathrm{X}=\mathrm{Cl} / \mathrm{Br} / \mathrm{OAc}$

Scheme 2

\section{Results and Discussion}

The analytical data for the ligand and complexes together with some physical properties are summarized in Table 1. The analytical data of the complexes correspond well with the general formula [MLX], where $\mathrm{M}=\mathrm{Cu}(\mathrm{II})$ and $\mathrm{Zn}(\mathrm{II}) ; \mathrm{L}=\mathrm{C}_{23} \mathrm{H}_{20} \mathrm{~N}_{5} \mathrm{O}$ and $\mathrm{X}=\mathrm{Cl} / \mathrm{Br} / \mathrm{OAc}$. 
Table 1. Physical characterization, analytical, molar conductance and magnetic susceptibility data of the Schiff base and its complexes

\begin{tabular}{|c|c|c|c|c|c|c|c|c|c|}
\hline \multirow[b]{2}{*}{ Compound } & \multirow[b]{2}{*}{ Colour } & \multirow{2}{*}{$\begin{array}{c}\text { Yield, } \\
\%\end{array}$} & \multirow{2}{*}{$\begin{array}{c}\text { Melt./ } \\
\text { Decomp. } \\
\text { Point, }{ }^{\circ} \mathrm{C}\end{array}$} & \multicolumn{4}{|c|}{ Found (Calcd) $\%$} & \multirow{2}{*}{$\begin{array}{c}\Lambda_{\mathrm{M}} \times 10^{-3} \\
\mathrm{mho} \mathrm{cm}^{2} \\
\mathrm{~mol}^{-1}\end{array}$} & \multirow{2}{*}{$\begin{array}{l}\mu_{\text {eff }}, \\
\text { B.M }\end{array}$} \\
\hline & & & & M & $\mathrm{C}$ & $\mathrm{H}$ & $\mathrm{N}$ & & \\
\hline HL & $\begin{array}{l}\text { Yello } \\
\text { w }\end{array}$ & 65 & 158 & - & $\begin{array}{c}72.18 \\
(72.06)\end{array}$ & $\begin{array}{c}5.54 \\
(5.48)\end{array}$ & & 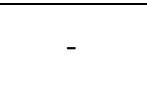 & \\
\hline [CuLCl] & Blue & 70 & 240 & $\begin{array}{c}13.23 \\
(13.21)\end{array}$ & $\begin{array}{c}57.73 \\
(57.38)\end{array}$ & $\begin{array}{c}4.12 \\
(4.16)\end{array}$ & $\begin{array}{l}14 . \\
(14 .\end{array}$ & 2.41 & 1.80 \\
\hline [CuLBr] & Green & 75 & 225 & $\begin{array}{c}12.58 \\
(12.09)\end{array}$ & $\begin{array}{c}52.42 \\
(52.53)\end{array}$ & $\begin{array}{c}3.58 \\
(3.81)\end{array}$ & $\begin{array}{c}13.68 \\
(13.32)\end{array}$ & 1.38 & 1.81 \\
\hline [CuLOAc] & Green & 71 & 254 & $\begin{array}{c}12.65 \\
(12.95)\end{array}$ & $\begin{array}{c}61.21 \\
(61.16)\end{array}$ & $\begin{array}{c}4.65 \\
(4.69)\end{array}$ & $\begin{array}{c}14.51 \\
(14.27)\end{array}$ & 1.26 & 1.78 \\
\hline$[\mathrm{ZnLCl}]$ & Brown & 69 & 295 & $\begin{array}{c}13.31 \\
(13.63) \\
\end{array}$ & $\begin{array}{r}57.41 \\
(57.10) \\
\end{array}$ & $\begin{array}{r}4.29 \\
(4.14) \\
\end{array}$ & $\begin{array}{c}14.34 \\
(14.48) \\
\end{array}$ & 2.31 & - \\
\hline
\end{tabular}

The magnetic susceptibility data of the complexes in the solid state shows that all the copper complex are paramagnetic and $\mathrm{Zn}$ (II) are diamagnetic at room temperature. The lower conductance values of the chelates support the non-electrolytic nature of the metal complexes $^{17}$.

\section{Mass spectra}

The FAB mass spectral data $(\mathrm{m} / \mathrm{z}$ values) of the Schiff base and its $[\mathrm{CuLCl}]$ complex were compared with their molecular formula weight. The mass spectra of Schiff base and its copper complex show a molecular ion peak at 383 and 481 respectively. These data are in good agreement with the proposed molecular formula for these complexes i.e., $\left[\mathrm{MC}_{23} \mathrm{H}_{20} \mathrm{~N}_{5} \mathrm{OX}\right]$ where $\mathrm{M}=\mathrm{Cu}$ (II) and $\mathrm{Zn}$ (II). In addition to molecular ion peak, the spectra exhibited peaks assignable to various fragments arising from the thermal cleavage of the ligand and its complex.

\section{IR spectra}

The IR spectrum of the ligand shows a strong band at $3500-3200 \mathrm{~cm}^{-1}$ region which is assigned to phenolic - $\mathrm{OH}$ group of salicylaldehyde moiety. Disappearance of these bands indicates the deprotonation of these groups upon coordination. In the spectrum of the Schiff base, the strong bands at $1645-1630 \mathrm{~cm}^{-1}$ region are attributable to $-\mathrm{C}=\mathrm{N}$ groups. On chelation, due to the possible drift of lone pair electron density towards the metal ion, the azomethine $-\mathrm{C}=\mathrm{N}$ band is expected to absorb at lower frequency in the complex. The observed band at $1610-1590 \mathrm{~cm}^{-1}$ region indicates the coordination of azomethine nitrogen to the metal. IR spectra of free Schiff base and its complexes show their characteristic pyridine ring vibration at 1045 and $660 \mathrm{~cm}^{-1}$ region, confirming the free existence of nitrogen present in the pyridine moiety. IR spectra of the complexes also show a new peaks at $510 \mathrm{~cm}^{-1}, 480 \mathrm{~cm}^{-1}$ and $430-440 \mathrm{~cm}^{-1}$ region due to the formation of M-N, M$\mathrm{O}, \mathrm{M}-\mathrm{Cl}$ or $\mathrm{M}-\mathrm{Br}$ bond respectively ${ }^{18}$.

\section{$H^{l}$ NMR spectra}

$\mathrm{H}^{1}$ NMR spectra of the Schiff base $(\mathrm{HL})$ and its $[\mathrm{ZnLCl}]$ complex were recorded in $\mathrm{CDCl}_{3}$. The Schiff base shows peak at $12.15 \mathrm{ppm}$ which are attributable to the phenolic $\mathrm{OH}$ group of salicylaldehyde moiety. Absence of this peak in the zinc complex favours the loss of phenolic - $\mathrm{OH}$ proton due to the coordination with zinc ion. A slight down field shift was noted in all other signals in the zinc complex. 


\section{Electronic absorption spectra of copper complexes}

The electronic absorption spectra serve as a useful tool to distinguish between the type 1, type 2 and type 3 blue copper proteins. Generally, the $\mathrm{Cu}$ (II) ion in natural blue copper site (type 1) shows one intense band at $600 \mathrm{~nm}$ with high extinction coefficient. It also exhibits another d-d transition in the near-infrared region $1000 \mathrm{~nm}$. The electronic absorption spectra serve as a useful tool to distinguish between the type 1, type 2 and type 3 blue copper proteins. Generally, the $\mathrm{Cu}$ (II) ion in natural blue copper site (type 1) shows one intense band at $600 \mathrm{~nm}$ with high extinction coefficient. It also exhibits another d-d transition in the near-infrared region $1000 \mathrm{~nm}^{19}$. For the type 2 and 3, the observed intensities of the visible absorption spectra indicate the transitions are $d-d$ nature and the energies are consistent with six or five or four (square planar) coordinate $\mathrm{Cu}(\mathrm{II})$, as the case may be. The observed transitions of the new complexes reported and are compared with those of the above spectral features. From the observed data, the $[\mathrm{CuLCl}]$ complex is mimic the type 1 blue copper model but other two complexes are non-model. It was further evidenced by cyclic voltammetry and ESR spectral data. The electronic spectral data of the compounds in $\mathrm{MeCN}$ solutions are summarized in Table 2.

Table 2. Electronic absorption spectral data of the compounds

\begin{tabular}{|c|c|c|c|c|c|}
\hline Compound & Transition & Assignment & $\begin{array}{l}\text { Molar extinction } \\
\text { coefficient, } \mathrm{cm}^{-1} \\
\text { mol }^{-1}\end{array}$ & Geometry & Model \\
\hline \multirow{2}{*}{ HL } & 279 & INCT & \multirow[t]{2}{*}{ 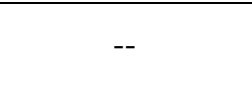 } & \multirow{2}{*}{--} & \multirow{2}{*}{--} \\
\hline & 246 & INCT & & & \\
\hline \multirow{4}{*}{ [CuLCl] } & 1012 & d-d & \multirow{4}{*}{$\begin{array}{c}168 \\
3840\end{array}$} & \multirow{4}{*}{ F. Tetrahedral } & \multirow{5}{*}{ Type 1} \\
\hline & 608 & d-d & & & \\
\hline & 296 & INCT & & & \\
\hline & 271 & INCT & & & \\
\hline \multirow{4}{*}{ [CuLBr] } & 863 & d-d & \multirow{4}{*}{$\begin{array}{l}120 \\
360\end{array}$} & \multirow{4}{*}{$\begin{array}{l}\text { Square } \\
\text { plannar }\end{array}$} & \\
\hline & 438 & d-d & & & \multirow{3}{*}{ Non-model } \\
\hline & 289 & INCT & & & \\
\hline & 254 & INCT & & & \\
\hline \multirow{4}{*}{ [CuLOAc] } & 746 & d-d & \multirow{4}{*}{$\begin{array}{c}96 \\
140\end{array}$} & \multirow{4}{*}{$\begin{array}{l}\text { Square } \\
\text { plannar }\end{array}$} & \multirow{4}{*}{ Non-model } \\
\hline & 488 & d-d & & & \\
\hline & 279 & INCT & & & \\
\hline & 258 & INCT & & & \\
\hline
\end{tabular}

\section{Electrochemistry}

The determination of redox potentials has an obvious application to elucidate the thermodynamically inaccessible species in naturally occurring organisms. The redox potentials of the synthetic models characteristics of the couple $\mathrm{Cu}(\mathrm{II}) / \mathrm{Cu}(\mathrm{I})$ are known to be influenced by the ligand parameters like donor atoms and structural features. The cyclic voltammogram of the copper complexes were recorded in $\mathrm{MeCN}$ at $27{ }^{\circ} \mathrm{C}$ using $0.1 \mathrm{M}$ solution of TBAB as the supporting electrolyte. It was scanned in the cathodic direction.

The $\left[\mathrm{CuLCl}\right.$ (Figure 1) complex exhibits a quasi reversible peak at $\mathrm{Ep}_{\mathrm{c}}=0.71 \mathrm{~V}$, characteristic of the reduction of $\mathrm{Cu}(\mathrm{II}) \rightarrow \mathrm{Cu}(\mathrm{I})$. The direct anodic peak corresponds to the reaction $\mathrm{Cu}(\mathrm{I}) \rightarrow \mathrm{Cu}(\mathrm{II})$ occurs at $\mathrm{Ep}_{\mathrm{a}}=0.74 \mathrm{~V}$. Such high positive redox redox couple $\mathrm{Cu}(\mathrm{II}) / \mathrm{Cu}(\mathrm{I})$ is an indicative feature shown by many naturally occurring blue copper proteins ${ }^{20,21}$. On these lines, the $[\mathrm{CuLCl}]$ complex can be considered as a model compound. The ESR results substantiate this fact. 
The cyclic voltammogram of the [CuLBr] complex (Figure 2) in $\mathrm{MeCN}$ solution shows a well defined redox process corresponding to the formation of the $\mathrm{Cu}(\mathrm{II}) / \mathrm{Cu}(\mathrm{III})$ couple at $\mathrm{Ep}_{\mathrm{a}}=0.50 \mathrm{~V}$ and the associated cathodic peak at $\mathrm{Ep}_{\mathrm{c}}=0.29 \mathrm{~V}$. This complex also shows another quasi reversible peak in the negative region characteristics for $\mathrm{Cu}$ (II) $\rightarrow \mathrm{Cu}$ (I) reduction at $\mathrm{Ep}_{\mathrm{c}}=-0.68 \mathrm{~V}$ with the associated anodic peak at $\mathrm{Ep}_{\mathrm{a}}=-0.38 \mathrm{~V}$ for $\mathrm{Cu}(\mathrm{I}) \rightarrow$ $\mathrm{Cu}$ (II) oxidation.

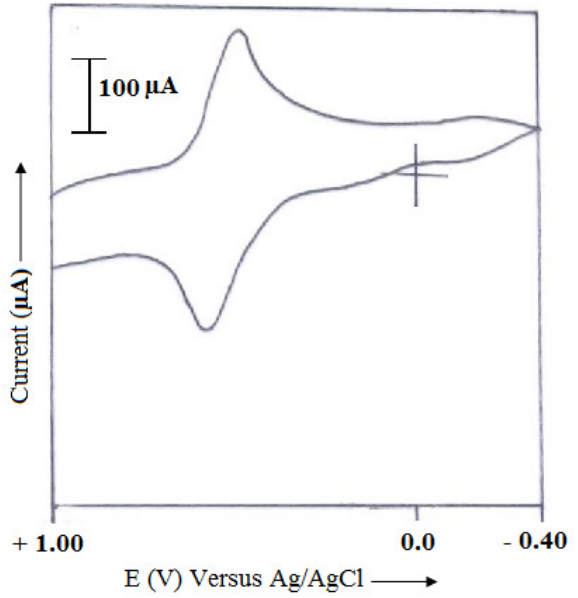

Figure 1. The cyclic voltammogram of the $[\mathrm{Cul}] \mathrm{Cl}$ complex in $\mathrm{MeCN}$ solution $(0.1 \mathrm{M}$ TBAB; scan rate $100 \mathrm{mVs}^{-1}$ )

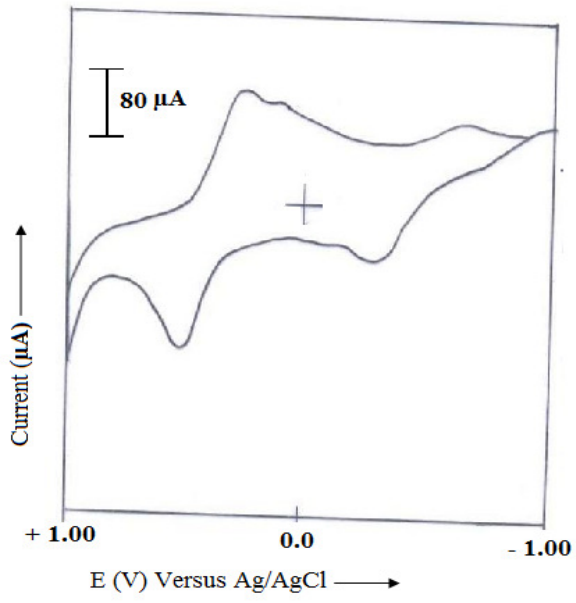

Figure 2. The cyclic voltammogram of the [CuLBr] complex in $\mathrm{MeCN}$ solution

The cyclic voltammogram of the [CuLOAc] complex in MeCN solution (Figure 3) shows a quasi reversible peak for the couple: $\mathrm{Cu}(\mathrm{II}) \rightarrow \mathrm{Cu}(\mathrm{III})$ at $\mathrm{Ep}_{\mathrm{a}}=0.53 \mathrm{~V}$ with the direct cathodic peak for $\mathrm{Cu}(\mathrm{III}) \rightarrow \mathrm{Cu}(\mathrm{II})$ at $\mathrm{Ep}_{\mathrm{c}}=0.40 \mathrm{~V}$. Further, it exhibits two irreversible peaks characteristic for $\mathrm{Cu}(\mathrm{II}) \rightarrow \mathrm{Cu}(\mathrm{I})\left(\mathrm{Ep}_{\mathrm{c}}=-0.48 \mathrm{~V}\right)$ and $\mathrm{Cu}(\mathrm{I}) \rightarrow \mathrm{Cu}(0)\left(\mathrm{Ep}_{\mathrm{c}}=-0.85 \mathrm{~V}\right)$ reduction. In the anodic side, the direct oxidation of $\mathrm{Cu}(0) \rightarrow \mathrm{Cu}$ (II) is observed with a strong stripping peak at $\mathrm{Ep}_{\mathrm{a}}=-0.13 \mathrm{~V}$. The two-electron nature of the process is established by the comparison of $\mathrm{Ip}_{\mathrm{c}}$ and $\mathrm{Ip}_{\mathrm{a}}$ values. Both $[\mathrm{CuLBr}]$ and $[\mathrm{CuLOAc}]$ complexes does show any significant positive redox potential which suggested that they are non-model complexes.

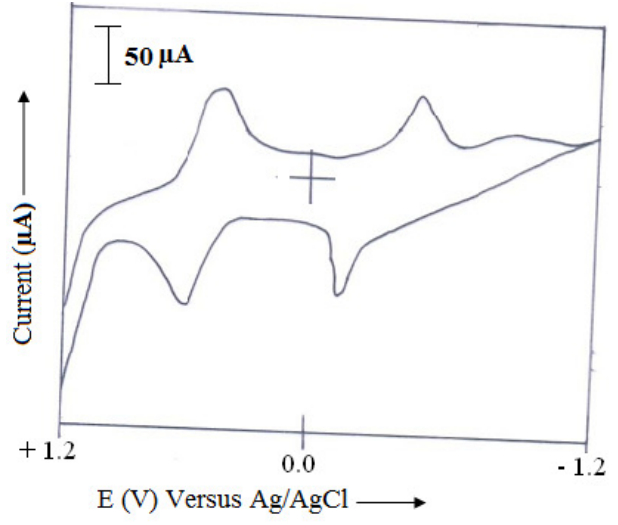

Figure 3. The cyclic voltammogram of the [CuLOAc] complex in $\mathrm{MeCN}$ solution 


\section{ESR spectra}

The different types of copper present in the natural systems are easily characterized based on their ESR spectral data. The alteration of geometry around the central metal ion in the synthetic complexes leads to a change in the values of $g_{l l}$ and $A_{l l}$. The change in the nature of coordinated anions surely affect the geometry and reduce the $A_{l l}$ values and increase the $g_{l l}$ values. The ESR spectra were recorded in $\mathrm{MeCN}$ solution at room temperature and at liquid nitrogen temperature. The result are summarized in the Table 3.

Table 3. The ESR parameters of copper complexes in MeCN solution at 300 and $77 \mathrm{~K}$

\begin{tabular}{cccccccc}
\hline Complex & $\mathrm{A}_{11}(\mathrm{G})$ & $\mathrm{A}_{\perp}(\mathrm{G})$ & $\mathrm{g}_{\text {ll }}$ & $\mathrm{g}_{\perp}$ & $\mathrm{A}_{\text {iso }}$ & $\mathrm{g}_{\text {iso }}$ & $\mathrm{g}_{\text {IIl }} \backslash \mathrm{A}_{\text {ll }}$ \\
\hline$[\mathrm{CuLCl}]$ & 78 & 38 & 2.30 & 2.06 & 51 & 2.15 & 295 \\
{$[\mathrm{CuLBr}]$} & 183 & 80 & 2.26 & 2.07 & 114 & 2.13 & 123 \\
{$[\mathrm{CuLOAc}]$} & 190 & 87 & 2.36 & 2.08 & 121 & 2.17 & 124 \\
\hline
\end{tabular}

A distortion of a square planar geometry of the complex into a distorted tetrahedron with any of the biomimetic nitrogen donors reduces $\mathrm{A}_{\| l}$ and increase $\mathrm{g}_{\| 1}$. Also the tetrahedral distortion could be readily gauged from the quotient $g_{\| l} \backslash A_{\| l}$. This method is convenient for indexing and identifying a tetrahedral distortion. The quotient ranges from 105 to $135 \mathrm{~cm}$ for square planar structures $^{22,23}$. But the quotient has been reported to increase markedly upon the introduction of tetrahedral distortion upto $250 \mathrm{~cm}$. It is observed that the quotients are high for the [CuLCl] complex of the present investigation which reveals that it is typical blue copper type 1 model. But other two complexes are square planar structure and also non-model complexes.

\section{References}

1. Senozan N M, J Chem Edu., 1974, 51(8), 503-505.

2. Edward I Solomon and Ryan G Hadt, Coord Chem Rev., 2011, 255(7), 774-789.

3. Singh L, Gupta P and Chakrawarti I, Asian J Chem., 2001, 13(2), 682-686.

4. Singh L, Gupta P, Chakrawarti I and Singh U, Asian J Chem., 2001, 13(2), 740-744.

5. Nair M K M. and Radhakrishnan P K, Synth React Inorg Met-Org Chem., 1995, 25(1), 57-70.

6. Joseph S and Radhakrishnan P K, Polyhedron, 1999, 18, 1884.

7. Agarwal R K and Singh G, Synth React Inorg Met-Org Chem., 1986, 16, 1183.

8. Raman N and Thangaraja C, Polish J Chem., 2005, 79(7), 1123-1134.

9. Nag J K, Pal S and Sinha C, Trans Met Chem., 2005, 30, 523-526.

10. Vaghasiya Y K, Nair R, Soni M, Baluja S and Chanda S, J Serb Chem Soc., 2004, 69, 991.

11. Selvakumar P M, Suresh E and Subramanian P S, Polyhedran, 2007, 26, 749-756.

12. Omar M M, Mahamed G G and Ibrahim A A, Spectrachimca Acta, 2009, 73A, 358- 369.

13. Deepa K, Madhu N T and Radhakrishnan P K, Synth React Inorg Met-Org Nano-Met Chem., 2005, 35, 883 -888.

14. Agrawal R K and Prakash B, Trans Met Chem., 2005, 30, 696-705.

15. Chandra S, Deepali J, Sharma A K and Pratibha S, Molecules, 2009, 14, 174-190.

16. Raman N, Syed Ali Fathima S and Dhaveethuraja J, Serb Chem Soc., 2008, 73, 1063-1071.

17. Geary W J, Coord Chem Rev., 1971, 7, 81 -122.

18. Nakamoto K, Infrared and Raman Spectra of Inorganic and Coordination Compounds, Wiley Inter science, III Edition, New York, 1977, 296-346.

19. Mcmillin D R, J Chem Edu., 1985, 62, 997-1001.

20. Armstrong F A, Hill H A O and Walton N J, Acc Chem Res., 1988, 21, 407, 1988.

21. Reinhammer B, Biochim Biophys Acta, 1972, 275, 245-259.

22. Sakaguhi U and Addision A W, J Chem Soc Dalton Trans., 1979, 600-608.

23. Thomas K R J, Chandrasekhar V, Scott S R, Hallford R and Cordes A W, J Chem Soc Dalton Trans., 1993, 25891993. 